\title{
The Evolutionary History, Diversity, and Ecology of Willows (Salix L.) in the European Alps
}

\author{
Natascha D. Wagner ${ }^{1}\left(\mathbb{D}, \mathrm{Li} \mathrm{He}^{2}\right.$ (D) and Elvira Hörandl ${ }^{1, *(D)}$ \\ 1 Department of Systematics, Biodiversity and Evolution of Plants (with Herbarium), University of Goettingen, \\ Untere Karspüle 2, 37073 Göttingen, Germany; natascha.wagner@uni-goettingen.de \\ 2 College of Forestry, Fujian Agriculture and Forestry University, Fuzhou 350002, China; heli198724@163.com \\ * Correspondence: elvira.hoerandl@biologie.uni-goettingen.de
}

check for updates

Citation: Wagner, N.D.; He, L.; Hörandl, E. The Evolutionary History, Diversity, and Ecology of Willows (Salix L.) in the European Alps. Diversity 2021, 13, 146. https:// doi.org/10.3390/d13040146

Academic Editors: Michael Wink and Juan Lorite

Received: 2 March 2021

Accepted: 26 March 2021

Published: 30 March 2021

Publisher's Note: MDPI stays neutral with regard to jurisdictional claims in published maps and institutional affiliations.

Copyright: (c) 2021 by the authors. Licensee MDPI, Basel, Switzerland. This article is an open access article distributed under the terms and conditions of the Creative Commons Attribution (CC BY) license (https:// creativecommons.org/licenses/by/ $4.0 /)$.

\begin{abstract}
The genus Salix (willows), with 33 species, represents the most diverse genus of woody plants in the European Alps. Many species dominate subalpine and alpine types of vegetation. Despite a long history of research on willows, the evolutionary and ecological factors for this species richness are poorly known. Here we will review recent progress in research on phylogenetic relationships, evolution, ecology, and speciation in alpine willows. Phylogenomic reconstructions suggest multiple colonization of the Alps, probably from the late Miocene onward, and reject hypotheses of a single radiation. Relatives occur in the Arctic and in temperate Eurasia. Most species are widespread in the European mountain systems or in the European lowlands. Within the Alps, species differ ecologically according to different elevational zones and habitat preferences. Homoploid hybridization is a frequent process in willows and happens mostly after climatic fluctuations and secondary contact. Breakdown of the ecological crossing barriers of species is followed by introgressive hybridization. Polyploidy is an important speciation mechanism, as $40 \%$ of species are polyploid, including the four endemic species of the Alps. Phylogenomic data suggest an allopolyploid origin for all taxa analyzed so far. Further studies are needed to specifically analyze biogeographical history, character evolution, and genome evolution of polyploids.
\end{abstract}

Keywords: biogeography; elevation; hybridization; phylogenomics; polyploidy; RAD sequencing; speciation; endemism

\section{Introduction}

Salix L. is the biggest genus in the family Salicaceae, comprising about 450 tree and shrub species that are mostly distributed in the Northern hemisphere. In Central Europe, Salix is the most species-rich genus of all woody plants. Many species inhabit high mountain systems, and the genus is highly diverse in the European Alps with approximately 33 species (Table 1; [1]). Alpine willows show a great morphological diversity in habit, ranging from tall trees to medium-sized to dwarf shrubs, and can be mostly discriminated by distinct characters of leaves, catkins, and fruits (Figure 1). Most species of the European Alps were already recognized and described during the 18th and 19th century (see Table 1). The subsequent work of Buser, Toepffer, and Rechinger [2-4] and, finally, the monograph of European and Russian species by Skvortsov [5] provided robust morphological circumscriptions of European species, including those occurring in the Alps.

From the 33 accepted species, 17 occur in the subalpine to the alpine zone, while the others are widely distributed in the montane forest zone and in the European lowlands. The relationships of species and their biogeographical history, however, remained under dispute. Only four alpine willows are endemic to the Alps, while most species have disjunct distributions in other European mountain systems and in the Arctic [1,5]. Thus far, it was unclear whether the observed willow diversity is the result of a radiation in the European mountain systems, specifically in the Alps, or, whether multiple origins and colonization of the mountain chain can be inferred. 
Table 1. List of Salix species of the European Alps.

\begin{tabular}{|c|c|c|c|c|c|c|}
\hline Taxon & Author (Year) * & Distribution & $\begin{array}{c}\text { Elevation and } \\
\text { Habitat }\end{array}$ & $\begin{array}{l}\text { Ploidy } \\
\text { Level }\end{array}$ & $\begin{array}{l}\text { Allopolyploid } \\
\text { Origins }\end{array}$ & $\begin{array}{c}\text { Phylogenetic } \\
\text { Position }\end{array}$ \\
\hline \multicolumn{7}{|l|}{ Subg. Salix } \\
\hline S. alba ** & L. (1753) & Europe to W. Asia & colline riversides & $4 \mathrm{x}$ & & [6] \\
\hline S. fragilis ${ }^{* *}$ & L. (1753) & Europe to W. Asia & colline riversides & $4 x$ & & $\begin{array}{l}\text { Wagner et al. } \\
\text { subm. }\end{array}$ \\
\hline S. pentandra & L. (1753) & $\begin{array}{l}\text { Europe to W. } \\
\text { Siberia }\end{array}$ & $\begin{array}{l}\text { montane-subalpine } \\
\text { riversides, shrubs }\end{array}$ & $4 x$ & & [6] \\
\hline S. triandra & L. (1753) & Eurasia, N-Africa & $\begin{array}{l}\text { colline-montane } \\
\text { riversides, lakes }\end{array}$ & $2 x$ & & [7] \\
\hline \multicolumn{7}{|c|}{ Subg. Vetrix s.l. (Chamaetia/Vetrix clade) } \\
\hline S. alpina & Scop. (1772) & $\begin{array}{l}\text { Alps, Carpathians, } \\
\text { Dinarids, Balcan }\end{array}$ & $\begin{array}{l}\text { subalpine screes, } \\
\text { rocks, snowbeds }\end{array}$ & $2 x$ & & [7] \\
\hline S. apennina & Skvorts. (1965) & Apennines, Alps & $\begin{array}{l}\text { colline-montane } \\
\text { shrubs }\end{array}$ & $6 x$ & & \\
\hline S. appendiculata & Vill. (1789) & $\begin{array}{c}\text { Alps, Central } \\
\text { European mts., } \\
\text { Dinarids }\end{array}$ & $\begin{array}{l}\text { montane-subalpine } \\
\text { shrubs }\end{array}$ & $2 x$ & & [7] \\
\hline S. aurita & L. (1753) & Europe to Siberia & $\begin{array}{l}\text { colline-montane } \\
\text { wetlands, bogs }\end{array}$ & $2 x$ & & [7] \\
\hline S. bicolor & $\begin{array}{l}\text { Ehrh. ex Willd. } \\
\text { (1796) }\end{array}$ & $\begin{array}{c}\text { Pyrenees, Massif } \\
\text { Central, Vosges, } \\
\text { Alps, Sudeten and } \\
\text { Carpathians }\end{array}$ & $\begin{array}{l}\text { montane-subalpine } \\
\text { shrubs }\end{array}$ & $3 x$ & & [7] \\
\hline S. breviserrata & Flod. (1940) & $\begin{array}{l}\text { Cantabrian mts., } \\
\text { Alps, Apennines }\end{array}$ & $\begin{array}{c}\text { Subalpine screes, } \\
\text { rocks }\end{array}$ & $2 x$ & & [7] \\
\hline S. caesia & Vill. (1789) & $\begin{array}{c}\text { Alps, and Central } \\
\text { Asia }\end{array}$ & Subalpine wetlands & $4 \mathrm{x}$ & $\begin{array}{l}\text { S. purpurea } \times \\
\text { repens }\end{array}$ & \\
\hline S. caprea & L. (1753) & Eurasia, lowland & $\begin{array}{l}\text { colline-subalpine } \\
\text { pioneer forests }\end{array}$ & $2 x$ & & [7] \\
\hline S. cinerea & L. (1753) & Eurasia, lowland & $\begin{array}{l}\text { colline-montane } \\
\text { wetlands, bogs }\end{array}$ & $4 x$ & $\begin{array}{c}\text { S. } \\
\text { appendiculata } \\
\times \text { aurita }\end{array}$ & [7] \\
\hline S. daphnoides & Vill. (1779) & $\begin{array}{l}\text { European lowland } \\
\text { and mountains }\end{array}$ & Montane shrubs & $2 x$ & & [7] \\
\hline S. eleagnos & Scop. (1772) & $\begin{array}{c}\text { Central and } \\
\text { Southern Europe }\end{array}$ & colline-montane & $2 x$ & & [7] \\
\hline S. foetida & $\begin{array}{c}\text { Schleich. ex DC. } \\
\text { (1805) }\end{array}$ & $\begin{array}{l}\text { Pyrenees, Alps, } \\
\text { Apennines }\end{array}$ & subalpine wetlands & $2 x$ & & [7] \\
\hline S. glabra & Scop. (1772) & Alps, Dinarids & $\begin{array}{l}\text { montane-subalpine } \\
\text { screes }\end{array}$ & $6 x$ & 2 parents? & [7] \\
\hline S. glaucosericea & Flod. (1943) & $\begin{array}{c}\text { Alps } \\
\text { circumboreal- }\end{array}$ & subalpine shrubs & $8 x$ & 3-4 parents? & [7] \\
\hline S. hastata & L. (1753) & $\begin{array}{c}\text { European } \\
\text { mountain system }\end{array}$ & subalpine shrubs & $2 x$ & & [7] \\
\hline $\begin{array}{c}S . \\
\substack{\text { hegetschweileri } \\
* * *}\end{array}$ & Heer (1840) & Alps & $\begin{array}{l}\text { montane-subalpine } \\
\text { shrubs, glacier } \\
\text { moraines }\end{array}$ & $4 x-6 x$ & $\begin{array}{l}\text { S. bicolor } \times \\
\text { myrsinifolia? }\end{array}$ & \\
\hline S. helvetica & Vill. (1789) & $\begin{array}{l}\text { Alps, Carpathians } \\
\text { circumarctic- }\end{array}$ & subalpine shrubs & $2 x$ & & [7] \\
\hline S. herbacea & L. (1753) & $\begin{array}{c}\text { European } \\
\text { mountain system }\end{array}$ & alpine snowbeds & $2 x$ & & [7] \\
\hline S. laggeri & Wimm. (1854) & Alps & subalpine shrubs & $4 x$ & $\begin{array}{l}\text { S. caprea } \times \\
\text { appendiculata }\end{array}$ & [7] \\
\hline S. mielichhoferi & Saut. (1849) & Alps & subalpine shrubs & $6 x$ & & \\
\hline
\end{tabular}


Table 1. Cont.

\begin{tabular}{|c|c|c|c|c|c|c|}
\hline Taxon & Author (Year) * & Distribution & $\begin{array}{c}\text { Elevation and } \\
\text { Habitat }\end{array}$ & $\begin{array}{l}\text { Ploidy } \\
\text { Level }\end{array}$ & $\begin{array}{l}\text { Allopolyploid } \\
\text { Origins }\end{array}$ & $\begin{array}{l}\text { Phylogenetic } \\
\text { Position }\end{array}$ \\
\hline S. myrtilloides & L. (1753) & Eurasia & montane bogs & $2 x$ & & \\
\hline S. myrsinifolia & Salisb. (1796) & $\begin{array}{l}\text { European } \\
\text { mountains }\end{array}$ & $\begin{array}{l}\text { montane wetlands, } \\
\text { riversides }\end{array}$ & $6 x$ & 3 parents? & [7] \\
\hline S. purpurea & L. (1753) & European lowland & $\begin{array}{l}\text { colline-subalpine } \\
\text { alluvials, moraines }\end{array}$ & $2 x$ & & [7] \\
\hline S. repens s.l. ${ }^{* * * *}$ & L. (1753) & Eurasia & $\begin{array}{l}\text { colline-montane wet } \\
\text { meadows }\end{array}$ & $2 x$ & & [7] \\
\hline S. retusa & L. (1759) & $\begin{array}{c}\text { European } \\
\text { mountain system } \\
\text { circumarctic- }\end{array}$ & $\begin{array}{l}\text { alpine snowbeds, } \\
\text { screes, rocks }\end{array}$ & $6 x$ & & \\
\hline S. reticulata & L. (1753) & $\begin{array}{c}\text { European } \\
\text { mountain system }\end{array}$ & alpine snowbeds & $2 x$ & & [7] \\
\hline S. serpillifolia & Scop. (1772) & Alps, Dinarids & alpine screes & $2 x$ & & [7] \\
\hline S. viminalis & L. (1753) & European lowland & $\begin{array}{l}\text { colline river and } \\
\text { lakesides }\end{array}$ & $2 x$ & & [7] \\
\hline $\begin{array}{c}\text { S. } \\
\text { waldsteininana }\end{array}$ & Willd. (1806) & $\begin{array}{l}\text { Alps, Dinarids, } \\
\text { Balcan }\end{array}$ & subalpine shrubs & $2 x$ & & [7] \\
\hline
\end{tabular}

${ }^{*}$ Full references of species names are available online at the International Plant Names Index [8]. Deviations from [1]: ** The lowland hybrid S. alba $\times$ S. fragilis $(S . \times$ rubens $)$ is not included here as a species as it is rare in the Alps and partly planted $[9,10] .{ }^{* * *}$ Records of S. phylicifolia from Switzerland, a Nordic species, refer to these species-allopolyploid origin needs to be investigated. ${ }^{* * * *}$ Includes $S$. rosmarinifolia, which we regard here as a subspecies of $S$. repens.

The evolutionary history of willows is strongly shaped by hybridization and polyploidization. Early authors already recognized the relatively high frequency of interspecific hybridization within the genus (reviewed by [11]), and molecular studies have confirmed hybrid combinations [9,12-15]. Many hybrids have been described from the European Alps with binomials, and even triple hybrids have been reported [2,4]. Willows are dioecious and have flowers with reduced corollas, probably due to a mixed wind- and insect-pollination system [16]. Dioecy, enforcing outcrossing, and the lack of pollinator specificity are often regarded as the main reasons for frequent hybridization [11,16]. Interspecific hybridization might lead to the evolution of new species if robust reproductive barriers are present [17]. Such opportunities arise frequently in secondary contact hybrid zones, when previously isolated and diverged species come into contact again. Quaternary climatic fluctuations have provided ample opportunities for the origin of such hybrid zones [17-19]. In the Alps, the many range fluctuations of species during the climatic oscillations of the Pleistocene have provided multiple secondary contact zones, as plants were forced to retreat into refugial areas during glacial periods, while warmer periods allowed recolonization of the alpine chain [19]. Eventually hybrids stay in the contact zone while parents retract to their original areas with their preferred niche. This ecogeographical displacement would facilitate hybrid speciation [20]. On the other hand, hybridization can lead to intermediate generations that are less adapted than their parental species [21], which would lead to introgression but not to the evolution of new species.

Until now the evolutionary importance of hybridization in willows, however, was unclear. While some authors regarded the formation of natural hybrids as negligible and assumed overestimated frequencies of hybridization because of misidentifications [22], others discussed hypotheses of allopolyploid origin of species $[5,13]$. Polyploidy is a frequent phenomenon in willows, approximately $40 \%$ of species worldwide are polyploid [23,24], which also fits the proportion of polyploids in the Alps (14 of $33=42 \%$ of species; see Table 1). The evolutionary origin, relationships, and evolution of polyploids have remained speculative until the advent of molecular studies. However, polyploidy may also act as important crossing barrier between species, and allow for sympatry even in mixed populations [11]. 

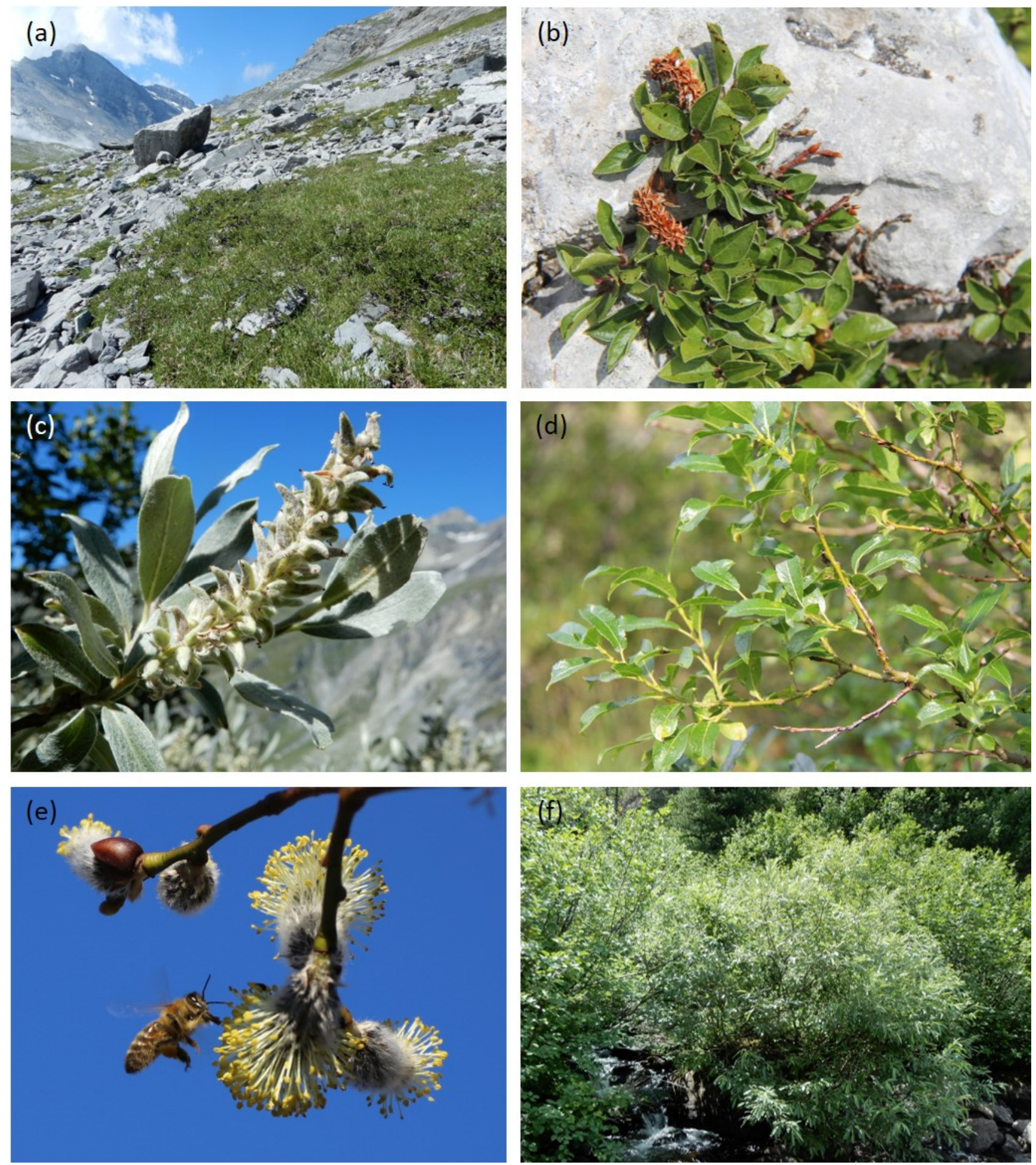

Figure 1. Selected Salix species that occur in the Alps. (a) S. breviserrata creeping dwarf shrub, (b) S. alpina with female catkins, (c) S. glaucosericea with female catkin, (d) S. mielichhoferi leaves, (e) S. aurita male catkins, (f) S. laggeri shrub. Photographs taken by N.W. and E.H.

Willows have adapted to a suite of different habitats across almost the entire elevational gradient from valley bottoms up to high alpine and subnival sites $[11,25,26]$. Willow stands often dominate the vegetation, and many species are characteristic for subalpine and alpine shrub communities, e.g., the associations Salicetum caesio-foetidae Br.-Bl. (1964), S. waldsteinianae Beger (1922), Salicetum helveticae Br.-Bl. et al. (1954), and alpine snowbeds, 
Salicetum retusae-reticulatae Br.-Bl. (1926) [26,27]. In addition to the elevation zone, soil pH is also important for their preferred habitat [28]. They, hence, differ in niche position as well as niche breadth to a variable degree. Because of the habitat differentiation, species co-occurring in similar habitats are apparently rarely sister species, see [7,29]. The only communality is a general preference of moist or wet soils, mostly on unshaded habitats. This preference is enforced by the need for rapid germination and immediate onset of photosynthesis in seedlings, as the seeds lack endosperm as reserve tissue; hence these recalcitrant seeds remain viable only for a few days [30]. Wet soils on open, light habitats are broadly available in alpine ecosystems, and willow species are perfect pioneer plants in these environments.

Despite their importance for the flora and vegetation of the Alps, the origins, relationships, and biogeographical histories of alpine willows are fairly unknown. The factors driving the extraordinarily high species diversity (for woody plants) are unexplored. The role of habitat differentiation for speciation processes and also for the maintenance of crossing barriers between sympatric species are poorly understood. Here, we will review progress of research of the last 20 years to increase our understanding of the evolution and ecology of alpine willows, with the hope to stimulate further research.

\section{Phylogenetic Relationships and Biogeography}

For a long time, molecular phylogenetic relationships between willow species, especially between arctic-alpine shrub species, remained unknown. This was mainly due to a lack of informative phylogenetic characters in traditional sequencing markers [6,31,32]. Nevertheless, molecular studies using plastid markers as well as complete plastome data were able to separate two clades: the more temperate tree willows (subg. Salix s.l.) and clade comprising trees and shrubs (subg. Chamaetia and Vetrix, summarized as the Chamaetia/Vetrix clade, or subg. Vetrix s.1.), but failed to resolve relationships within the latter [6,31,33-36]. Salix triandra, a widely distributed lowland species, was in sister position to the Chamaetia/Vetrix clade, while most willow species occurring in the Alps fall into the shrub willow clade. However, three widely distributed tree willows that belong to subgenus Salix also occur in valleys of the Alps: S. alba, S. fragilis, and S. pentandra. Recent studies based on whole-plastome data revealed each of them as monophyletic (Wagner et al. submitted), and they were closely related to each other. Salix alba and S. fragilis were in sister position in the plastome tree, and they can be separated with population genetic nuclear markers [9]. More recent analyses using Restriction site Associated DNA (RAD) sequencing data were able to reconstruct robust phylogenetic trees for Eurasian shrub species of the Chamaetia/Vetrix clade [7,29]. The findings confirmed the monophyly of the Chamaetia/Vetrix clade but did not confirm the traditional treatment as two distinct subgenera, which was also shown by other molecular studies [6,36].

The backbone topologies of traditional markers were used to reconstruct the temporal evolution of Salicaceae and the genus Salix. The age of the genus Salix was estimated as 43.8 Ma and for the Chamaetia/Vetrix clade as $23 \mathrm{Ma}$, respectively [36]. A much younger age for the genus Salix of $16.9 \mathrm{Ma}$ and approximately $8 \mathrm{Ma}$ for the Chamaetia/Vetrix clade, respectively, was estimated based on plastome data [37]. Based on RAD sequencing data, He et al. [38] used a secondary calibration based on Wu et al.'s dating [36] and estimated an age of about $21 \mathrm{Ma}$ for the Eurasian and $16 \mathrm{Ma}$ for the Pan-Himalayan clade. However, estimations for the "Eurasian" clade were obscured by the small representative sampling in all these studies. In any case, all age estimations for the crown group diversification of alpine species predate the climatic oscillations of the Quaternary. The age estimates by $\mathrm{Wu}$ et al. [36] would fit best the age of the main orogeny of the Alps in the Late Oligocene to the early Miocene [19].

The results of $[7,29]$ revealed that the 25 included species that occur in the Alps were each monophyletic (Figure 2). Salix reticulata was in sister position to the remaining species. The somewhat isolated phylogenetic position of this circumpolar distributed species was also shown in [39] and was already assumed by [5]. Taxonomically described species 
pairs appeared in sister relationships (e.g., S. foetida and S. waldsteinana, S. breviserrata, and S. alpina), but otherwise, previous sectional classifications [5] were poorly supported (Figure 2).

The lack of a worldwide sampling still hampers the reconstruction of biogeographical history of willows. However, a few trends can already be recognized. In contrast to the observed radiation in the Pan-Himalayan clade, specifically in the Hengduan Mountains [38], the willow species of the European Alps did not share a common ancestor, with only $12 \%$ endemic species, indicating a diverse evolutionary and biogeographical history. First colonizations may be concomitant with the European oldest fossil evidence of Salix in the Middle Oligocene, probably following migration from Asia from representatives of the Turgai Flora of Kazakhstan and environs [40]. All clades also consist of species from "outside the Alps", e.g., S. starkeana from Scandinavia in clade II (Figure 2). This pattern might be even more evident with an increased sampling. The arctic alpine-species included here (S. reticulata, S. herbacea, and S. hastata) are only distantly related to each other, suggesting multiple independent origins and colonization events of previously glaciated areas. A pattern of multiple colonizations of the Arctic via long-distance dispersal (LDD) was found in S. herbacea and also in other arctic species from various genera [41]. LDD in willows is easily feasible by wind dispersal of the very light-weighted seeds equipped with a bundle of hairs. Moreover, the other Scandinavian willows included here (S. lanata, S. lapponum, and S. nummularia) appeared in different clades in the phylogeny (Figure 2). Altogether, this fits to a general pattern proposed by Skvortsov [5] that closely related willow species separate geographically, often over large distances in Eurasia.

Compared to other European mountains systems, similar patterns of spatiotemporal diversification occur probably in the Pyrenees and the Cantabrian mountains. The subalpine-alpine species of these mountain chains (S. reticulata, S. retusa, S. herbacea, S. pyrenaica, S. breviserrata, S. hastata, S. bicolor, and S. ceretana = S. lapponum subsp. ceretana, [42]) are already included in our molecular phylogeny, see Figure 2 (records of $S$. foetida for the Pyrenees need confirmation). As in the Alps, these species are scattered over all clades and are separate from lowland species via different elevations and ploidy levels. Other than the alpine species, the diploid level is predominant, including the two Pyrenean endemics S. pyrenaica and S. ceretana. The scarcity of polyploids in the Iberian Peninsula might fit a more general trend of polyploids in higher latitudes [43]. A more detailed investigation of the biogeographical history of willows of the European mountain system, however, is still wanted.

Within the Alps, a distinct geographical pattern is apparent in sect. Arbuscella and sect. Myrtosalix. The first group comprises the western alpine and Pyrenean (?) S. foetida, the Eastern Alpine-Dinarid S. waldsteiniana, the Nordic S. arbuscula and S. kazbekensis from the Caucasus. Sect. Myrtosalix comprises the western alpine and Cantabrian $S$. breviserrata, the eastern alpine and Carpathian S. alpina, and the Nordic S. myrsinites [5]. The East-West pattern in the Alps of S. waldsteiniana/S. foetida and S. alpina/S. breviserrata were traditionally recognized as vicariant pairs [11], but it is unclear whether an actual geographical or climatic barrier, e.g., the ice-shields during glaciations of the Pleistocene, separated these species or whether they originated in mountain areas outside the Alps and reached the Alps via LDD. The role of ecological niche differentiation according to slightly different soil preferences is unclear [1], and putative hybrid zones in the overlapping areas have been reported for both pairs [11]. Whether ecogeographical displacement plays a role in these hybrid zones needs further investigation [20]. 
classification

subg. Chamaetia

subg. Vetrix

distribution

$\square$ in the Alps

exclusively outisde the Alps

habit

$\square$ dwarf shrubs $<50 \mathrm{~cm}$

shrubs $50-150 \mathrm{~cm}$

shrubs/trees $>150 \mathrm{~cm}$

elevation

$\square$ colline
$\square$ montane
$\square$ subalpine
alpine
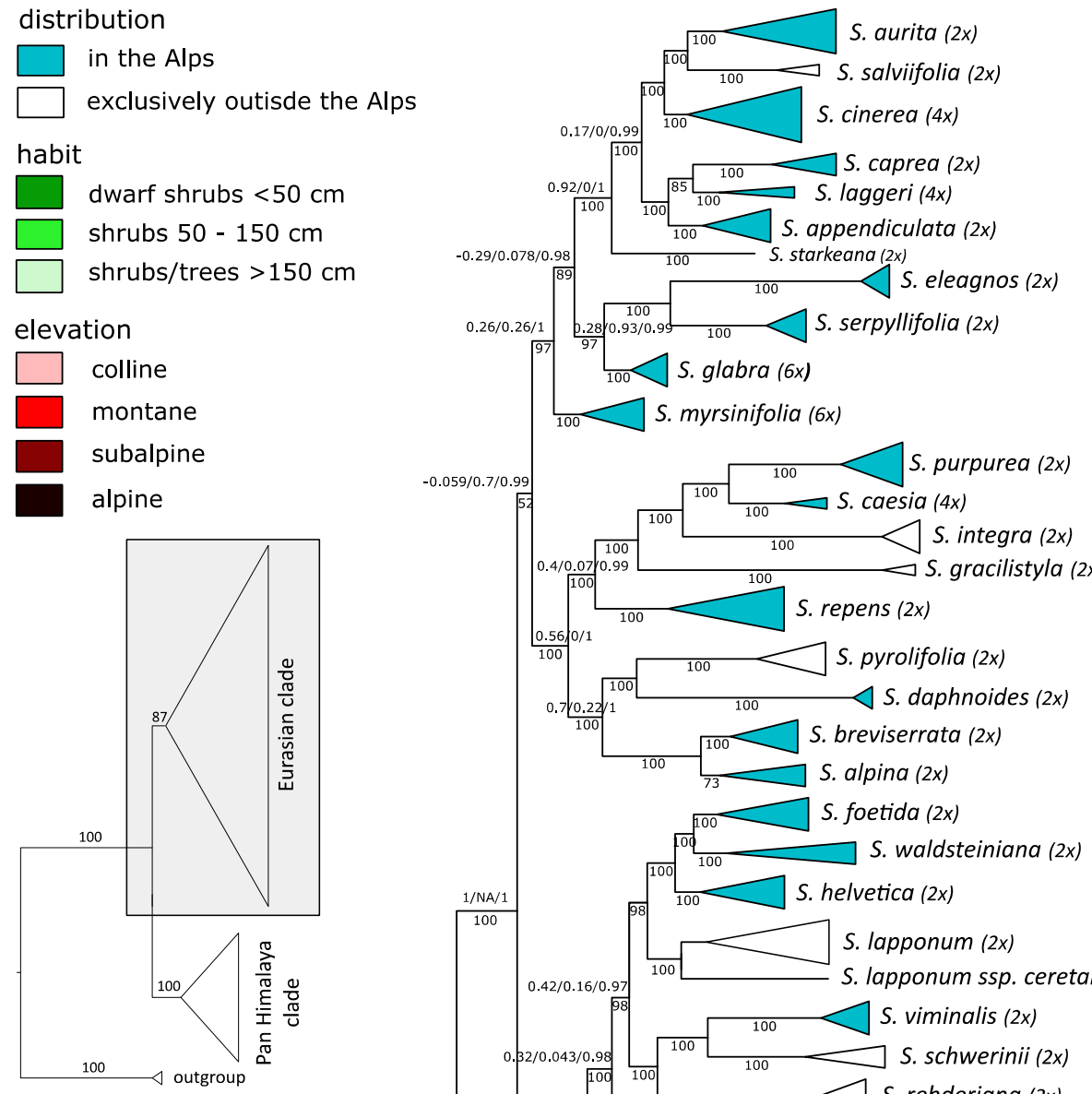

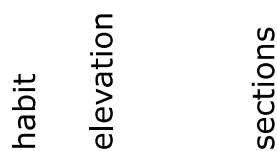

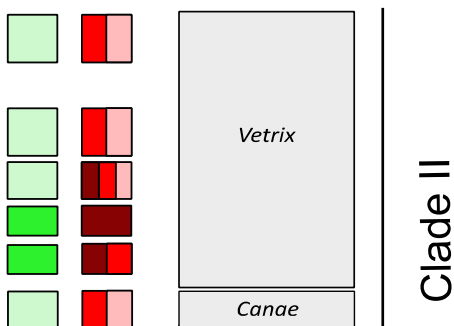

Glabrella

Nigricantes
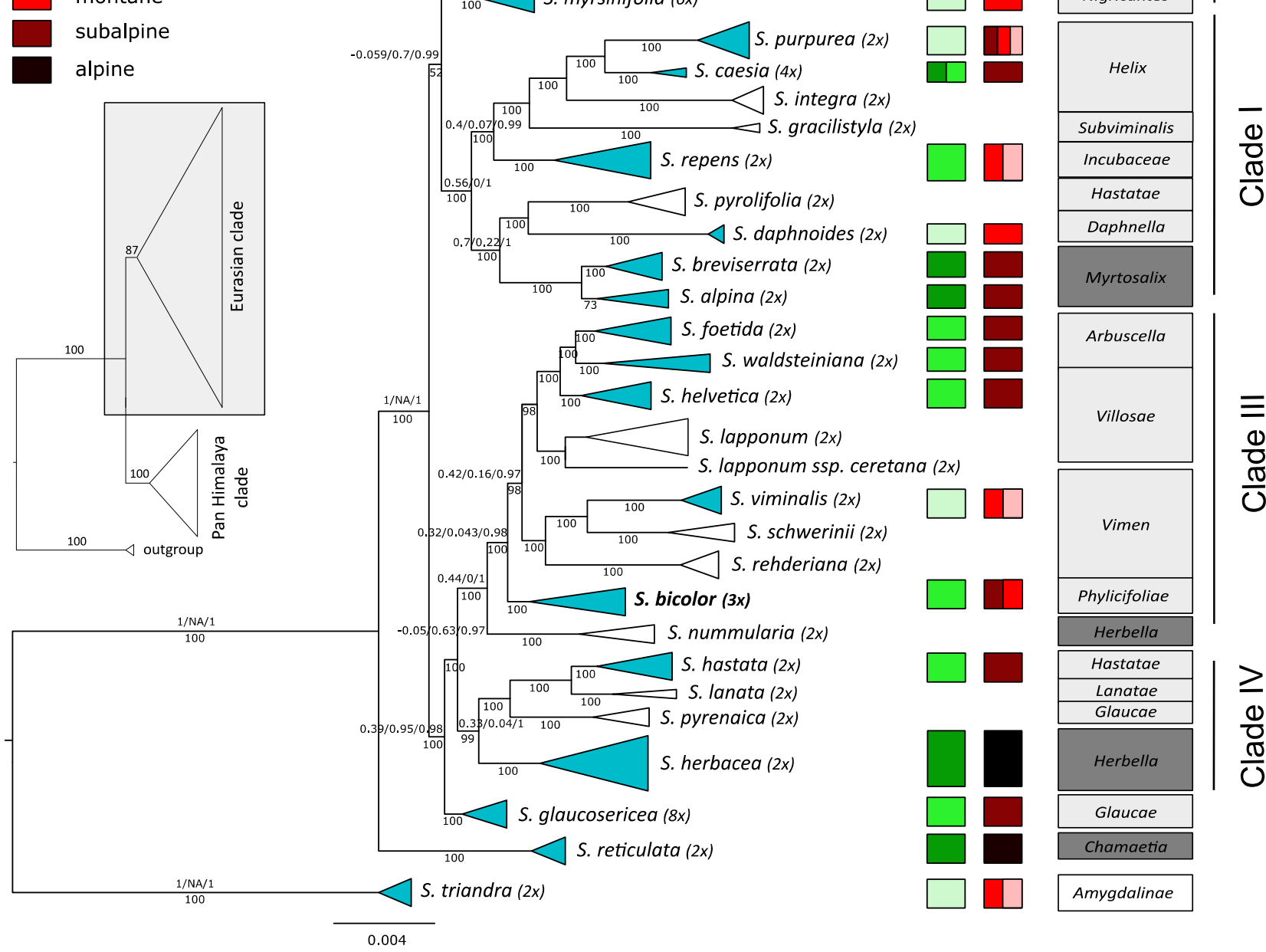

Daphnella

Myrtosalix

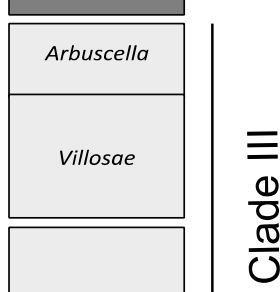

Figure 2. Summarized RAxML phylogeny of 133 accessions representing 35 species of the Salix Chamaetia/Vetrix clade based on 23,393 RAD loci. Bootstrap support (BS) values below and quartet sampling (QS) values above branches. Species occurring in the Alps are indicated by blue color. Habit and elevational distribution are indicated in colored boxes behind species names following color legend. Sectional classification is shown in gray boxes, traditional subgeneric classification is indicated by dark gray (subg. Chamaetia) and light gray (subg. Vetrix) (edited after [7], elevation after [1]).

There are only four species endemic to the Alps, and they are all polyploids (tetraploid S. laggeri, tetra- to hexaploid S. hegetschweileri, hexaploid S. mielichhoferi, and octoploid S. glaucosericea). Hence, neopolyploidy rather than relic endemism is probably the main driver for the autochthonous origins of species. Recently, a first phylogenomic study on polyploid shrub species was published [7]. The included polyploid species occurred in 
three of the four observed clades. The tetraploid species were nested within the major clades, e.g., S. cinerea and S. laggeri in clade II (both section Vetrix) and S. caesia in clade I (section Helix; Figure 2), whereas the higher polyploids included so far were situated in more basal positions of the phylogeny (S. myrsinifolia, S. glabra, S. glaucosericea). The study discovered that the polyploid species were of allopolyploid origin (see below). The triploid species $S$. bicolor was situated in clade III.

\section{Sectional Classification and Character Evolution}

The traditional sectional classification was only partly reflected by molecular data (Figure 2). While all included species of section Vetrix or section Vimen group together, other sections, such as Herbella or Hastatae appeared polyphyletic. Therefore, some morphological characters seem to be more suitable for detecting natural lineages than others. For example, Salix species that occur in cold, hostile environments of the arctic and alpine zone show a characteristic dwarf growth [44]. Some species grow only a few centimeters in height and have leaves that are only a few millimeters in size (e.g., S. serpillifolia). Based on their morphological and ecological similarity, the five sections of these highly specialized dwarf willows were traditionally lumped in the subgenus Chamaetia [5]. However, analysis of morphological character evolution revealed a multiple origin of the dwarf shrubs as an adaptation to arctic-alpine environments [29]; Figure 2. Thus, the classification of a distinct subgenus Chamaetia was not supported. Instead, alpine species evolved the dwarf habit at least five times independently. The convergent evolution of these characteristics as adaptations to the environmental and climatic conditions was also suggested [5].

The RAD sequencing phylogeny showed that the occurrence in subalpine and alpine zones is not restricted to a single clade (Figure 2). On the contrary, all clades include species that colonize alpine elevations. One extreme example is clade I, in which the high-alpine dwarf shrub $S$. serpillifolia appeared in close relationship to the colline-montane tree $S$. eleagnos. This hints to an independent invasion of (sub)alpine zones in different clades, sometimes followed by speciation, e.g., in case of $S$. breviserrata and S. alpina. However, no radiation in high elevations could be observed within the alpine willows.

\section{Evolution and Ecology of Species}

\subsection{Evolution of Crossing Barriers}

Geographical isolation and allopatric/peripatric speciation over larger areas, especially over the whole European mountain system, may have been major drivers of diversification processes in willows [5]. Hence, the Alps were colonized multiple times, probably also in different time periods. Nowadays, distribution patterns of species in the Alps are largely overlapping, and few species exclude each other geographically [1], enabling hybridization. Interspecific hybridization might on the one hand blur species boundaries, on the other hand could have a creative role via introgression or hybrid speciation [45]. Hence, major questions for understanding evolution of alpine willows are as follows: How can species barriers be kept in sympatry? What is the evolutionary relevance of ancient and recent hybridization in willows? We will focus here on the Chamaetia/Vetrix clade, which comprises the great majority of species.

Crossing barriers in sympatry might be upheld by different ecology. The major ecological differentiation of species occurs according to habitat, elevation and associated temperature gradients, and to some extent, soil $\mathrm{pH}$ [28]. These examples show that currently available data do not hint toward the evolution of lineages with similar ecological adaptations but rather at the niche differentiation of closely related species. Other potential ecological crossing barriers are likely missing. The ambophilous pollination system of willows and the lack of morphological differentiation of flowers rather hamper the evolution of specialized pollination syndromes [16]. Phenological differences do exist but usually follow simply elevational preferences [1]. In the subalpine/alpine zone, the short summers rather enforce synchronous flowering of the respective willow species. Hybrid formation is clearly more frequent in species with overlapping preferences of elevation $(67 \%$ of crosses, 
Figure 3). Other ecological factors as crossing barriers are poorly explored for alpine willows or are not species specific. Herbivore resistance patterns have a complex genetic background [46]. Mycorrhiza communities are not different between willow species, but the community structure within species appears to follow altitudinal gradients [47,48]. Crossing barriers due to genetic divergence of species may mainly act between members of different subgenera, as very few tree species of subg. Salix hybridize with members of the Chamaetia / Vetrix clade [5]. However, the crossing barriers between subgenera are not exclusive, and potentially different sex determination systems might provide crossing barriers [49]. Within the Chamaetia/Vetrix clade, however, genetic divergence is in general so low that only population genomic markers resolved relationships. Hybrids are formed not only between sister species but also between members of different clades (see Figure 3). Some clustering of related species is observed around the diploids S. helvetica-S. waldsteiniana-S. foetida. Indeed, these hybrid combinations are found most commonly in subalpine shrub communities [2]. Another clustering of related species with more frequent hybrid formation occurs in sect. Vetrix (S. appendiculata to S. aurita) at lower elevations. Different ploidy levels are regarded as strong genomic crossing barriers, and indeed the great majority of willow hybrids (78\%) have parents with the same ploidy level (Figure 3). Remarkably, for some frequently co-occurring species pairs with different ploidy levels, no hybrids have been ever reported: e.g., S. serpillifolia/S. retusa; S. reticulata/S. retusa; S. waldsteiniana/S. glabra; S. caesia/S. foetida, and S. glaucosericea/S. helvetica, among others. These species appear to be completely reproductively isolated by different ploidy levels. However, most willow hybrids appear as single or few individuals, without evolutionary potential, and only very few crosses do form populations [2]. Only these populations are of interest for understanding hybrid evolution in willows and will be discussed in the following sections.

\subsection{Hybridization in Secondary Contact Zones as a Consequence of Climatic Changes}

The climatic fluctuations during the Pleistocene caused range fluctuations of species, with range expansion in warmer periods and contraction in refugial areas in the colder periods when the Alps were covered by an ice shield [19]. Hence, warmer periods provide opportunities for secondary contact hybridization of previously diverged species. These processes might have happened repeatedly during the Pleistocene and during the recolonization of the Alps after the last glacial maximum (starting ca. 10,000 years ago), eventually also resulting in allopolyploid speciation (see "Section 3.3". However, to reconstruct such events in a spatial-temporal framework a fine-scale dating of the Chamaetia/Vetrix clade would be necessary but is not yet available.

Climatic oscillations in the Holocene caused altitudinal shifts of the alpine flora as also observed during global warming of the last 150 years [50,51]. The process of glacier retreat during the recent climate change happens probably faster than in previous time periods. Additionally, human influence on the landscape, such as grazing or construction work for tourism, can influence the vegetation of the subalpine-alpine zone. Local upward migration of lowland species and contact with subalpine/alpine species can result in a breakdown of ecological crossing barriers related to elevation. For willows, such scenarios happen most frequently on glacier forefields as a pioneer habitat where light and wet soil conditions are suitable for willows [50]. 


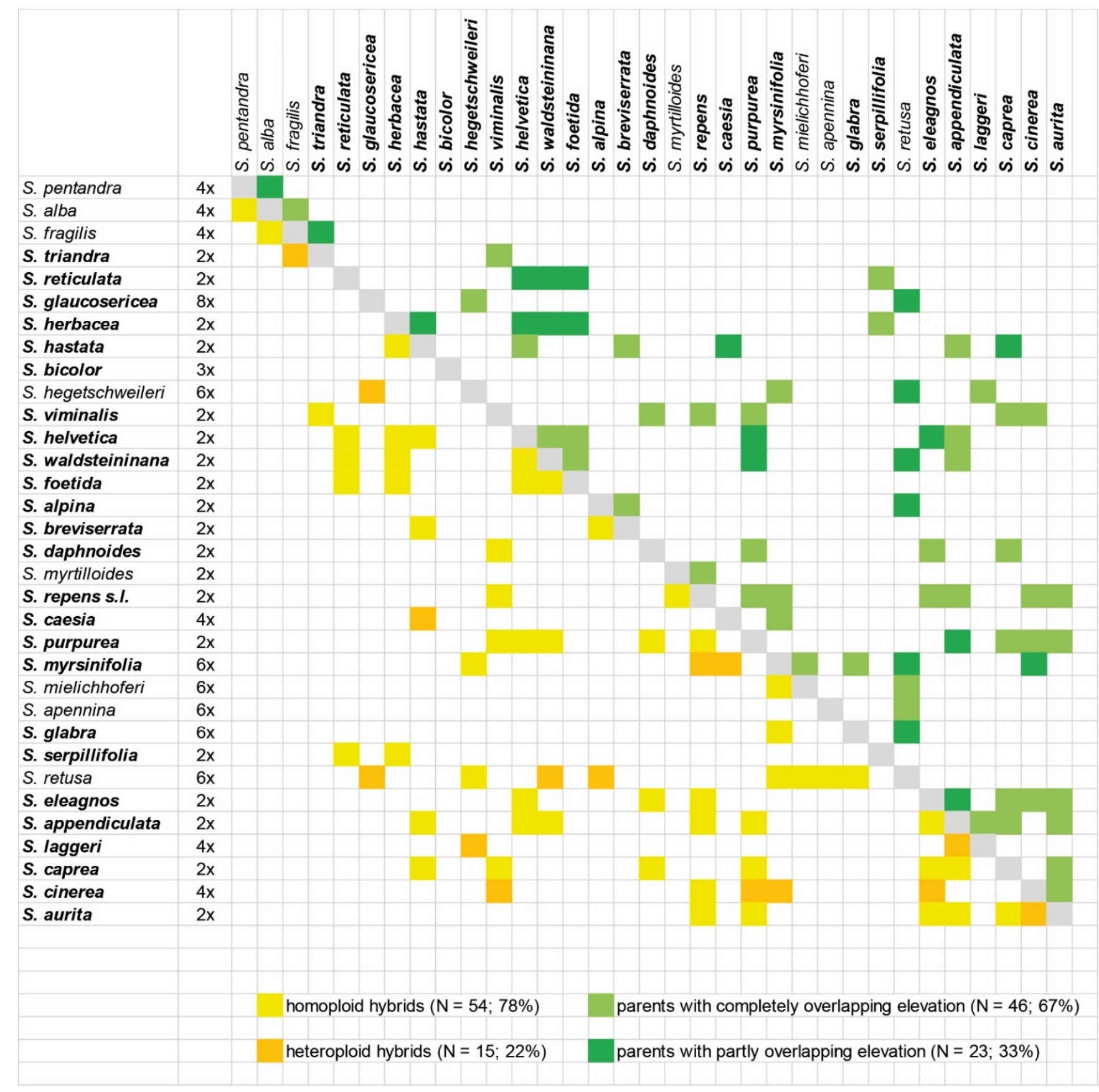

Figure 3. Crossing table of the extant 69 hybrid combinations between species in the Alps [2,4,11,15]. Doubtful crosses were excluded). The order of species follows phylogenetic relationships (see Figure 2), species included in the phylogeny are marked in bold face.

The Gletschboden at the origin of the river Rhone in Switzerland is such a habitat for studying secondary contact hybridization. The valley is situated at approximately $1700 \mathrm{~m}$ above sea level, in the subalpine zone. The Gletschboden has been ice free since 1912 , and in the 1980s 20 willow species had already colonized the area, partly forming dense shrubs [52]. In 2009 and 2010, field studies of the senior author (E.H.) revealed several intermediate individuals, mostly hybrids of subalpine shrub S. helvetica with the lowland pioneer $S$. purpurea. Molecular studies confirmed the hybrid nature of $S$. helvetica $\times$ S. purpurea. This hybrid already formed populations, it also appeared on the Morteratsch Glacier forefield and might be more widespread in the Alps [15,53]. The hybrids showed a high fertility, and offspring could be raised from seeds that were formed 
spontaneously in the wild [53]. By using RAD sequencing markers, it could be ascertained that the adults on the Gletschboden still belonged to the F1 hybrid generation, whereas the F2 plants mostly represented backcrosses but only few hybrid $\times$ hybrid crosses. Lack of segregation distortion in the F2 facilitates introgression rather than the evolution of chromosomal barriers for hybrid speciation. Introgression is probably the evolutionary fate of forthcoming hybrid generations and can also transfer adaptive features to hybrids, as potentially observed in growth form, which already in the F2 resembled the stout stature of subalpine $S$. helvetica [50].

Detailed vegetation studies on the Gletschboden revealed that the hybrids occupy the drier and more acid microhabitats on the glacier moraines of the forefield in a mosaic-like pattern [15,53]. This fits the theoretical prediction that homoploid hybrids must separate ecologically from their parents to successfully establish self-standing populations [54]. Under this aspect, glacier retreat in alpine regions opens opportunities for hybrid formation and habitat differentiation. In the long term, these habitats might be lost again for willows with successive reforestation, and hybrids would have to move further upward in the present alpine zone in a scenario of continued global warming. Under these aspects, it is hard to predict whether homoploid hybrids will be winners or losers of climate change.

With continuing global warming, alpine plant species might be threatened by extinction until the end of the twenty-first century, due to the dramatic shrinking of range size at highest summits of the Alps [51]. In general, endemic (herbaceous) plants will face the highest losses [51]. The alpine willows S. herbacea, S. reticulata, and S. retusa included in this study would probably reduce their range size in the Alps. However, due to their general large distribution area, they would not face extinction. These species can be cultivated in the lowlands under appropriate garden conditions [55], and hence they possibly could survive also in a general warmer climate on suitable, local microhabitats in the Alps. Other willow species were so far not investigated under the aspect of climate change in the Alps.

\subsection{Polyploids: Allopolyploid Speciation}

Other than homoploid hybridization, polyploidy plays an important role for the speciation of alpine willows. In addition to the high proportion (42\%) of polyploid species, it is remarkable that all four endemic species of the Alps are polyploids (Table 1). Three of them (S. mielichhoferi, S. hegetschweileri, and S. glaucosericea) exhibit high ploidy levels (hexaploid to octoploid) and according to RAD sequencing analyses probably have a complex evolutionary allopolyploid origin, potentially involving more than two parental species [7]. Due to their hybrid origin, the relationships of these species within the Chamaetia/Vetrix clade cannot yet be finally pinpointed, but there is no obvious relationship of these high polyploids to other lineages of the European Alpine System. Two species are putative relatives of arctic-boreal species, namely S. glaucosericea to S. glauca, and S. hegetschweileri to $S$. phylicifolia [5]. These hypotheses need to be tested using molecular data. This arctic-alpine relation would not fit the patterns of herbaceous endemics of the Alps, which originated mostly in lineages of the European Alpine System [56]. In woody plants, diversification processes might span over larger geographical scales than in herbs.

The success of polyploid willows in the subalpine and alpine zone could follow a general trait of polyploids to colonize colder climatic regions [43]. The background for this phenomenon, however, could be manifold. Polyploidization could happen more frequently in colder areas via unreduced gamete formation as a consequence of temperature shocks, e.g., freezing, during meiosis $[57,58]$. On the other hand, polyploids could be more stressresistant under extreme conditions [59]. Polyploidy confers a higher diversity of alleles and epialleles and, hence, more flexibility of genetic and epigenetic control mechanisms, gene expression, and gene subfunctionalization [60]. Moreover, higher heterozygosity can provide heterosis effects and buffer effects of deleterious recessive mutations via duplicated gene copies [60]. Epigenetic features, e.g., methylation, can change under different climatic conditions and, hence, provide a flexible mechanism of controlling gene expression, which 
is specifically important for perennial, long-lived plants [61]. Altogether, these genomic features provide higher phenotypic plasticity and adaptive potentials for polyploids [60,62].

Willow genomes have undergone ancient polyploidization events, the Salicoid lineage (including poplars and willows) shares an ancient genome duplication $[63,64]$ that can be traced in the genomes of diploid willows $[49,65]$. Purifying selection on duplicated genes and loss of paralogs happened faster in willows than in poplars, resulting in the faster evolution of willow lineages. This process may explain the much higher species diversity of Salix compared to that of Populus [66]. Hence, both paleopolyploidy and neopolyploidy have shaped willow genomes. In the diploid species S. purpurea, genome-wide association studies have elucidated the molecular background for morphological and physiological traits [67]. However, so far, no study linked genomic data and neopolyploidy to the niche differentiation and ecological preferences of willows.

In the Alps, there is no linear relationship of higher ploidy levels to higher altitude as most polyploids occur in the subalpine zone. The alpine species at highest elevations are predominantly diploid (S. reticulata, S. serpillifolia, S. herbacea), while S. retusa represents the only alpine polyploid in the Alps. This species has a disjunct distribution in the European Alpine System with different cytotypes from hexaploid to decaploid [68]. A potential limitation for high-alpine polyploid species might be the preference of polyploids for more nutrient-rich soils, which are not available under high alpine conditions $[43,44]$. The alpine diploids, e.g., S. herbacea, appear to be adapted to nutrient-poor soils, and this species suffers more from herbivory on nutrient-rich soils [69]. Other potential benefits of polyploidy, e.g., shifts in the mode of reproduction [70], do not apply to willows: a potential breakdown of self-compatibility systems is meaningless in willows as they are dioecious; a shift to apomixis has been reported for one Japanese species based on crossing experiments [71], but any embryological confirmation of apomictic development is still missing [72].

For three tetraploids willows, the evolutionary origin could be disentangled due to analysis of the genomic composition of single-nucleotide polymorphism (SNP) markers within species [7]. Salix laggeri, an endemic subalpine shrub, which occurs scattered in the western and southwestern Alps, originated likely from hybridization of the diploids $S$. appendiculata and S. caprea. Salix appendiculata grows in montane gorges or on riversides and is common in subalpine shrub vegetation, whereas $S$. caprea is a pioneer species on drier habitats from the colline to the subalpine zone. Salix laggeri occurs exclusively as subalpine shrubs, mostly on rocky ground. The diploid parental species occur also nowadays sympatrically in the Alps and hybridize in the upper montane and subalpine zone [73], making an autochthonous allopolyploid origin of S. laggeri likely. However, the species cannot be regarded as a recent hybrid because already $36.6 \%$ of genomic single-nucleotide polymorphisms (SNPs) are specific for S. laggeri, indicating a distinct evolutionary lineage [7]. The tetraploid level provides an efficient crossing barrier against the parents. Hybrids between S. laggeri and S. appendiculata do occur occasionally in mixed stands but develop aborted catkins and fruits [73] (Hörandl, personal observations). The genomic proportions of $S$. laggeri coming from putative backcrossing to parental species was fairly low, approximately $12 \%$ of SNPs.

Another allotetraploid with fairly well-resolved relationships is the subalpine shrub S. caesia [7]. This species originated probably from the hybridization of S. purpurea and S. repens, two predominantly montane, diploid species. Salix caesia combines specific SNPs and morphological characteristics of both parental species. Furthermore, in this case, a fairly high proportion of species-specific SNPs (19.2\%) indicate a separately evolving lineage, and amounts of backcrossing are fairly low (approximately $18 \%$ of SNPs). Recent hybrids with the parents have not yet been reported, as S. caesia does not occur together with the parental species. Salix purpurea is a widespread pioneer plant on alluvials, screes, and moraines, whereas $S$. repens is a species of colline to montane swamps and bogs. Salix caesia established in its own ecological niche in subalpine wetlands, characterizing the plant community Salicetum caesio-foetidae in which neither of the parents would occur. 
The third tetraploid analyzed so far is the widespread lowland species S. cinerea, which originated probably from a hybrid of S. appendiculata and S. aurita [7]. Extant hybridization has been reported with both parental species (Figure 3), they often co-occur in wetlands, and bogs. However, this relationship needs further confirmation as many other species of the section Vetrix have not yet been sampled [7].

\section{Conclusions and Outlook}

Even though the interest in Salix was high due to their ecological and economical importance, the study of willows was hampered for decades by a lack of suitable molecular tools [31] (Wagner et al. submitted). Throughout the last years, newly developed molecular marker systems along with the development of new analytical tools massively increased our understanding of this diverse genus. Only recently, it has become possible to reconstruct the first resolved phylogeny for shrub willows (Chamaetia/Vetrix clade) [29]. Hybrids could be analyzed and the evolutionary impacts of secondary contact zones on willow speciation could be studied [50]. Next to that, the first analyses of polyploid species are also promising to disentangle the complex evolution further [7].

However, most studies focused on single species [68] or distinct geographical regions [38]. In future, the developed techniques could be used to further investigate the evolution and biogeography of genus Salix on a world-wide scale. Especially, because many species (and sections) are widely distributed. To analyze the phylogenetic relationships, the sampling needs to be increased. Based on a robust comprehensive phylogeny, a molecular dating is possible as well as biogeographical analysis to reconstruct the spatiotemporal evolution of willows. Based on these data, the questions of whether and how several radiations as well as the climatic fluctuations during the Pleistocene enhanced speciation in shrub willows could be examined. The data could be combined with ecological factors. This might be useful given the increased number of secondary contact zones with ongoing global warming, as well as the threat to high-alpine willows due to habitat loss [51].

A well-resolved phylogeny including all described sections and several species per section from different regions of the distributional range makes it possible to test for morphological character evolution. Such studies can entangle potential adaptations to alpine conditions [29,38]. Providing a genetic framework by nuclear markers combined with morphological character coding, will also help to disentangle the taxonomic challenges in Salix and, thus, be useful for further taxonomic work in the genus. Further perspectives for understanding functional traits are available via whole-genome sequencing studies. A couple of studies focused so far on sex determination systems in willows $[49,65,74]$, but genome sequencing data will also help to understand functional traits [67].

An increased sampling of the phylogeny will also help to study allopolyploid species, with specific emphasis on higher polyploids. Only if all putative parental species and lineages, respectively, are sampled, the origin and evolution of polyploids can be fully analyzed. The availability of the updated S. purpurea reference genome [75] as well as ongoing development of bioinformatic tools will support these efforts. Genome analysis of polyploids is promising for understanding their evolutionary history [76]. Additionally, the naturally occurring hybrid populations can be analyzed using the developed pipelines.

Population genomic markers will be also useful to study the phylogeography and evolutionary history of diploid alpine species. The origin and migration routes of species within the European Alpine System are fairly unknown. Little is known about postglacial migration routes out of marginal refugia. For the high-alpine S. serpillifolia, a Nunatak survival has been proposed [77], but for the subalpine shrub species, such a scenario seems unlikely. The location of glacial refugia has not yet been investigated. This would be of specific interest for understanding the putative diploid vicariant species pairs in the Alps and their hybrid zones. Do these zones represent the overlapping areas of a parapatric speciation process, or do they represent secondary contact zones after a postglacial recolonization? These studies should be combined with ecological studies to better understand the role of habitat differentiation for speciation in willows. 
Author Contributions: Conceptualization, N.D.W. and E.H.; funding acquisition, N.D.W.; writing: N.D.W., L.H. and E.H. All authors have read and agreed to the published version of the manuscript.

Funding: This research was funded by the Deutsche Forschungsgemeinschaft (DFG), grant number WA3684/2-1.

Acknowledgments: We thank Manuela Winkler for the invitation to contribute to this symposium and anonymous reviewers for their useful comments. We acknowledge support by the Open Access Publication Funds of the Göttingen University.

Conflicts of Interest: The authors declare no conflict of interest. The funders had no role in the design of the study; in the collection, analyses, or interpretation of data; in the writing of the manuscript; or in the decision to publish the results.

\section{References}

1. Aeschimann, D.; Lauber, K.; Moser, D.; Theurillat, J.-P. Flora Alpina. Ein Atlas Sämtlicher 4500 Gefäßßpflanzen der Alpen; Haupt: Bern, Switzerland, 2004.

2. Buser, R. Kritische Beiträge zur Kenntnis der schweizerischen Weiden. Ber. Schweiz. Bot. Ges. 1940, 50, 567-788. [CrossRef]

3. Toepffer, A. Salices Bavariae. Versuch einer Monographie der bayerischen Weiden unter Berücksichtigung der Arten der mitteleuropäischen Flora. Ber. Bayer. Bot. Ges. 1915, 15, 17-233.

4. $\quad$ Rechinger, K.H. Salix. In Illustrierte Flora von Mitteleuropa III/1, 2nd ed.; Hegi, G., Ed.; Hanser: Munich, Germany, $1957 ;$ pp. 44-135.

5. Skvortsov, A. Willows of Russia and Adjacent Countries; University of Joensuu: Joensuu, Finland, 1999.

6. Chen, J.H.; Sun, H.; Wen, J.; Yang, Y.P. Molecular phylogeny of Salix L. (Salicaceae) inferred from three chloroplast datasets and its systematic implications. Taxon 2010, 59, 29-37. [CrossRef]

7. Wagner, N.D.; He, L.; Hörandl, E. Phylogenomic Relationships and Evolution of Polyploid Salix Species Revealed by RAD Sequencing Data. Front. Plant Sci. 2020, 11. [CrossRef]

8. IPNI. 2020 International Plant Names Index. The Royal Botanic Gardens Kew, Harvard University Herbaria \& Libraries and Australian National Botanic Gardens. Available online: http: / www.ipni.org (accessed on 2 March 2021).

9. Meneghetti, S.; Barcaccia, G.; Paiero, P.; Lucchin, M. Genetic characterization of Salix alba L. and Salix fragilis L. by means of different PCR-derived marker systems. Plant Biosyst. 2007, 141, 283-291. [CrossRef]

10. Oberprieler, C.; Dietz, L.; Harlander, C.; Heilmann, J. Molecular and phytochemical evidence for the taxonomic integrity of Salix alba, S-fragilis, and their hybrid S. x rubens (Salicaceae) in mixed stands in SE Germany. Plant Syst. Evol. 2013, 299, 1107-1118. [CrossRef]

11. Hörandl, E.; Florineth, F.; Hadacek, F. Weiden in Österreich und Angrenzenden Gebieten [Willows in Austria and Adjacent Regions], 2nd ed.; University of Agriculture: Vienna, Austria, 2012; 164p.

12. Hardig, T.M.; Brunsfeld, S.J.; Fritz, R.S.; Morgan, M.; Orians, C.M. Morphological and molecular evidence for hybridization and introgression in a willow (Salix) hybrid zone. Mol. Ecol. 2000, 9, 9-24. [CrossRef]

13. Barcaccia, G.; Meneghetti, S.; Albertini, E.; Triest, L.; Lucchin, M. Linkage mapping in tetraploid willows: Segregation of molecular markers and estimation of linkage phases support an allotetraploid structure for Salix alba x Salix fragilis interspecific hybrids. Heredity 2003, 90, 169-180. [CrossRef] [PubMed]

14. Triest, L.; De Greef, B.; De Bondt, R.; Van Slycken, J. RAPD of controlled crosses and clones from the field suggests that hybrids are rare in the Salix alba-Salix fragilis complex. Heredity 2000, 84, 555-563. [CrossRef] [PubMed]

15. Gramlich, S.; Sagmeister, P.; Dullinger, S.; Hadacek, F.; Hörandl, E. Evolution in situ: Hybrid origin and establishment of willows (Salix L.) on alpine glacier forefields. Heredity 2016, 116, 531-541. [CrossRef] [PubMed]

16. Karrenberg, S.; Kollmann, J.; Edwards, P.J. Pollen vectors and inflorescence morphology in four species of Salix. Plant Syst. Evol. 2002, 235, 181-188. [CrossRef]

17. Abbott, R.; Albach, D.; Ansell, S.; Arntzen, J.W.; Baird, S.J.E.; Bierne, N.; Boughman, J.W.; Brelsford, A.; Buerkle, C.A.; Buggs, R.; et al. Hybridization and speciation. J. Evol. Biol. 2013, 26, 229-246. [CrossRef] [PubMed]

18. Hewitt, G.M. Genetic consequences of climatic oscillations in the Quaternary. Phil. Trans. R. Soc. Lond. B Biol. Sci. 2004, 359, 183-195. [CrossRef] [PubMed]

19. Hewitt, G.M. Quaternary phylogeography: The roots of hybrid zones. Genetica 2011, 139, 617-638. [CrossRef] [PubMed]

20. Kadereit, J.W. The geography of hybrid speciation in plants. Taxon 2015, 64, 673-687. [CrossRef]

21. Abbott, R.; Brennan, A.C. Altitudinal gradients, plant hybrid zones and evolutionary novelty. Philos. Trans. R. Soc. B 2014, 369, 20130346. [CrossRef] [PubMed]

22. Neumann, A. Die mitteleuropäischen Salix-Arten. Mitt. Forstl. Bundes-Vers. Wien 1981, 134, 1-152.

23. Suda, Y.; Argus, G.W. Chromosome numbers of some North American Salix. Brittonia 1968, 20, 191-197. [CrossRef] 
24. Suda, Y.; Argus, G.W. Chromosome numbers of some North American arctic and boreal Salix. Can. J. Bot. 1969, 47, 859. [CrossRef]

25. Martini, F.; Paiero, P. I Salici d'Italia; Edizione Lint: Trient, Italy, 1988.

26. Ellenberg, H.; Leuschner, C. Vegetation Mitteleuropas mit den Alpen, 6th ed.; Eugen Ulmer: Stuttgart, Germany, 2010.

27. Grabherr, G.; Mucina, L. Die Pflanzengesellschaften Österreichs. Teil II; G. Fischer: Jena, Germany, 1993.

28. Schiechtl, H.M. Weiden in der Praxis_Die Weiden Mitteleuropas, ihre Verwendung und Bestimmung; Patzer: Berlin, Germany; Hannover, Germany, 1992; 130p.

29. Wagner, N.D.; Gramlich, S.; Hörandl, E. RAD sequencing resolved phylogenetic relationships in European shrub willows (Salix L. subg. Chamaetia and subg. Vetrix) and revealed multiple evolution of dwarf shrubs. Ecol. Evol. 2018, 8, 8243-8255. [CrossRef] [PubMed]

30. Karrenberg, S.; Suter, M. Phenotypic trade-offs in the sexual reproduction of Salicaceae from flood plains. Am. J. Bot. 2003, 90, 749-754. [CrossRef]

31. Percy, D.M.; Argus, G.W.; Cronk, Q.C.; Fazekas, A.J.; Kesanakurti, P.R.; Burgess, K.S.; Husband, B.C.; Newmaster, S.G.; Barrett, S.C.H.; Graham, S.W. Understanding the spectacular failure of DNA barcoding in willows (Salix): Does this result from a trans-specific selective sweep? Mol. Ecol. 2014, 23, 4737-4756. [CrossRef] [PubMed]

32. Leskinen, E.; Alstrom-Rapaport, C. Molecular phylogeny of Salicaceae and closely related Flacourtiaceae: Evidence from 5.8 S, ITS 1 and ITS 2 of the rDNA. Plant Syst. Evol. 1999, 215, 209-227. [CrossRef]

33. Azuma, T.; Kajita, T.; Yokoyama, J.; Ohashi, H. Phylogenetic relationships of Salix (Salicaceae) based on rbcL sequence data. Am. J. Bot. 2000, 87, 67-75. [CrossRef] [PubMed]

34. Lauron-Moreau, A.; Pitre, F.E.; Argus, G.W.; Labrecque, M.; Brouillet, L. Phylogenetic Relationships of American Willows (Salix L.; Salicaceae). PLoS ONE 2015, 10. [CrossRef]

35. Savage, J.A.; Cavender-Bares, J. Habitat specialization and the role of trait lability in structuring diverse willow (genus Salix) communities. Ecology 2012, 93, S138-S150. [CrossRef]

36. Wu, J.; Nyman, T.; Wang, D.C.; Argus, G.W.; Yang, Y.P.; Chen, J.H. Phylogeny of Salix subgenus Salix s.l. (Salicaceae): Delimitation, biogeography, and reticulate evolution. BMC Evol. Biol. 2015, 15. [CrossRef]

37. Zhang, L.; Xi, Z.X.; Wang, M.C.; Guo, X.Y.; Ma, T. Plastome phylogeny and lineage diversification of Salicaceae with focus on poplars and willows. Ecol. Evol. 2018, 8, 7817-7823. [CrossRef] [PubMed]

38. He, L.; Wagner, N.D.; Hörandl, E. RAD sequencing data reveal a radiation of willow species (Salix L.; Salicaceae) in the Hengduan Mountains and adjacent areas. J. Syst. Evol. 2021, 59, 44-57. [CrossRef]

39. Liu, X.; Wang, Z.S.; Wang, D.S.; Zhang, J.G. Phylogeny of Populus-Salix (Salicaceae) and their relative genera using molecular datasets. Biochem. Syst. Ecol. 2016, 68, 210-215. [CrossRef]

40. Collinson, M.E. The early fossil history of Salicaceae-A brief review. Proc. R. Soc. Edinb. Sect. B Biol. Sci. 1992, 98, 155-167. [CrossRef]

41. Alsos, I.G.; Eidesen, P.B.; Ehrich, D.; Skrede, I.; Westergaard, K.; Jacobsen, G.H.; Landvik, J.Y.; Taberlet, P.; Brochmann, C. Frequent long-distance plant colonization in the changing Arctic. Science 2007, 316, 1606-1609. [CrossRef] [PubMed]

42. Blanco, P. Salix. In Flora Iberica; Castroviejo, S., Cirujano, S., Montserrat, P., Munoz Garmendia, F., Paiva, J., Eds.; Real Jardin Botanico: Madrid, Spain, 1993; pp. 477-517.

43. Rice, A.; Smarda, P.; Novosolov, M.; Drori, M.; Glick, L.; Sabath, N.; Meiri, S.; Belmaker, J.; Mayrose, I. The global biogeography of polyploid plants. Nat. Ecol. Evol. 2019, 3, 265-273. [CrossRef] [PubMed]

44. Körner, C. Alpine Plant Life. Functional Plant Ecology of High Mountain Systems; Springer: Berlin/Heidelberg, Germany, 2003.

45. Abbott, R.J.; Hegarty, M.J.; Hiscock, S.J.; Brennan, A.C. Homoploid hybrid speciation in action. Taxon 2010, 59, 1375-1386. [CrossRef]

46. Fritz, R.S.; Hochwender, C.G.; Brunsfeld, S.J.; Roche, B.M. Genetic architecture of susceptibility to herbivores in hybrid willows. J. Evol. Biol. 2003, 16, 1115-1126. [CrossRef] [PubMed]

47. Arraiano-Castilho, R.; Bidartondo, M.I.; Niskanen, T.; Clarkson, J.J.; Brunner, I.; Zimmermann, S.; Senn-Irlet, B.; Frey, B.; Peintner, U.; Mrak, T.; et al. Habitat specialisation controls ectomycorrhizal fungi above the treeline in the European Alps. N. Phytol. 2021, 229, 2901-2916. [CrossRef] [PubMed]

48. Arraiano-Castilho, R.; Bidartondo, M.I.; Niskanen, T.; Zimmermann, S.; Frey, B.; Brunner, I.; Senn-Irlet, B.; Hörandl, E.; Gramlich, S.; Suz, L.M. Plant-fungal interactions in hybrid zones: Ectomycorrhizal communities of willows (Salix) in an alpine glacier forefield. Fungal Ecol. 2020, 45. [CrossRef]

49. He, L.; Jia, K.-H.; Zhang, R.-G.; Wang, Y.; Shi, T.-L.; Li, Z.-C.; Zeng, S.-W.; Cai, X.-J.; Wagner, N.D.; Hörandl, E.; et al. Chromosomescale assembly of the genome of Salix dunnii reveals a male-heterogametic sex determination system on chromosome 7. Mol. Ecol. Resour. 2021, in press. [CrossRef] [PubMed]

50. Gramlich, S.; Wagner, N.D.; Hörandl, E. RAD-seq reveals genetic structure of the F-2-generation of natural willow hybrids (Salix L.) and a great potential for interspecific introgression. BMC Plant Biol. 2018, 18. [CrossRef] [PubMed]

51. Dullinger, S.; Gattringer, A.; Thuiller, W.; Moser, D.; Zimmermann, N.E.; Guisan, A.; Willner, W.; Plutzar, C.; Leitner, M.; Mang, T.; et al. Extinction debt of high-mountain plants under twenty-first-century climate change. Nat. Clim. Change 2012, 2, 619-622. [CrossRef] 
52. Lautenschlager-Fleury, D.; Lautenschlager-Fleury, E. Der Gletschboden, ein Weidenparadies. Bauhinia 1985, 8, 89-98.

53. Gramlich, S.; Hörandl, E. Fitness of natural willow hybrids in a pioneer mosaic hybrid zone. Ecol. Evol. 2016, 6, 7645-7655. [CrossRef] [PubMed]

54. Rieseberg, L.H.; Willis, J.H. Plant speciation. Science 2007, 317, 910-914. [CrossRef] [PubMed]

55. Newsholme, C. Willows. The Genus Salix; Timber Press: Portland, OR, USA, 1992.

56. Kadereit, J.W. The role of in situ species diversification for the evolution of high vascular plant species diversity in the European Alps-A review and interpretation of phylogenetic studies of the endemic flora of the Alps. Perspect. Plant Ecol. Evol. Syst. 2017, 26, 28-38. [CrossRef]

57. Ramsey, J.; Schemske, D.W. Pathways, mechanisms, and rates of polyploid formation in flowering plants. Annu. Rev. Ecol. Syst. 1998, 29, 467-501. [CrossRef]

58. Schinkel, C.C.F.; Kirchheimer, B.; Dullinger, S.; Geelen, D.; De Storme, N.; Hörandl, E. Pathways to polyploidy: Indications of a female triploid bridge in the alpine species Ranunculus kuepferi (Ranunculaceae). Plant Syst. Evol. 2017, 303, 1093-1108. [CrossRef] [PubMed]

59. Schoenfelder, K.P.; Fox, D.T. The expanding implications of polyploidy. J. Cell Biol. 2015, 209, 485-491. [CrossRef] [PubMed]

60. Comai, L. The advantages and disadvantages of being polyploid. Nat. Rev. Genet. 2005, 6, 836-846. [CrossRef]

61. Syngelaki, E.; Schinkel, C.C.F.; Klatt, S.; Hörandl, E. Effects of temperature treatments on cytosine-methylation profiles of diploid and autotetraploid plants of the alpine species Ranunculus kuepferi (Ranunculaceae). Front. Plant Sci. 2020, 11. [CrossRef]

62. Feliner, G.N.; Casacuberta, J.; Wendel, J.F. Genomics of Evolutionary Novelty in Hybrids and Polyploids. Front. Genet. 2020, 11, 21. [CrossRef]

63. Tuskan, G.A.; DiFazio, S.; Jansson, S.; Bohlmann, J.; Grigoriev, I.; Hellsten, U.; Putnam, N.; Ralph, S.; Rombauts, S.; Salamov, A.; et al. The genome of black cottonwood, Populus trichocarpa (Torr. \& Gray). Science 2006, 313, 1596-1604. [CrossRef] [PubMed]

64. Li, M.M.; Wang, D.Y.; Zhang, L.; Kang, M.H.; Lu, Z.Q.; Zhu, R.B.; Mao, X.X.; Xi, Z.X.; Ma, T. Intergeneric Relationships within the Family Salicaceae s.l. Based on Plastid Phylogenomics. Int. J. Mol. Sci. 2019, 20, 3788. [CrossRef]

65. Zhou, R.; Macaya-Sanz, D.; Rodgers-Melnick, E.; Carlson, C.H.; Gouker, F.E.; Evans, L.M.; Schmutz, J.; Jenkins, J.W.; Yan, J.Y.; Tuskan, G.A.; et al. Characterization of a large sex determination region in Salix purpurea L. (Salicaceae). Mol. Genet. Genom. 2018, 293, 1437-1452. [CrossRef] [PubMed]

66. Hou, J.; Wei, S.Y.; Pan, H.X.; Zhuge, Q.; Yin, T.M. Uneven selection pressure accelerating divergence of Populus and Salix. Hortic. Res. 2019, 6, 11. [CrossRef] [PubMed]

67. Carlson, C.H.; Gouker, F.E.; Crowell, C.R.; Evans, L.; DiFazio, S.P.; Smart, C.D.; Smart, L.B. Joint linkage and association mapping of complex traits in shrub willow (Salix purpurea L.). Ann. Bot. 2019, 124, 701-715. [CrossRef] [PubMed]

68. Kosinski, P.; Sliwinska, E.; Hilpold, A.; Boratynski, A. DNA ploidy in Salix retusa agg. only partly in line with its morphology and taxonomy. Nord. J. Bot. 2019, 37. [CrossRef]

69. Little, C.J.; Wheeler, J.A.; Sedlacek, J.; Cortes, A.J.; Rixen, C. Small-scale drivers: The importance of nutrient availability and snowmelt timing on performance of the alpine shrub Salix herbacea. Oecologia 2016, 180, 1015-1024. [CrossRef] [PubMed]

70. Hojsgaard, D.; Hörandl, E. The Rise of Apomixis in Natural Plant Populations. Front. Plant Sci. 2019, 10, 358. [CrossRef]

71. Ikeno, S. On hybridization of some species of Salix. Ann. Bot. 1922, 36, 175-191. [CrossRef]

72. Hojsgaard, D.; Klatt, S.; Baier, R.; Carman, J.G.; Hörandl, E. Taxonomy and biogeography of apomixis in angiosperms and associated biodiversity characteristics. Crit. Rev. Plant. Sci. 2014, 33, 414-427. [CrossRef]

73. Lautenschlager-Fleury, D.; Lautenschlager-Fleury, E. Salix laggeri Wimmer-Monographie einer wenig bekannten Weide. Bauhinia 1984, 8, 149-156.

74. Li, W.; Wu, H.T.; Li, X.P.; Chen, Y.N.; Yin, T.M. Fine mapping of the sex locus in Salix triandra confirms a consistent sex determination mechanism in genus Salix. Hortic. Res. 2020, 7. [CrossRef] [PubMed]

75. Brereton, N.J.B.; Gonzalez, E.; Marleau, J.; Guidi Nissim, W.; Labrecque, M.; Joly, S.; Pitre, F.E. Comparative Transcriptomic Approaches Exploring Contamination Stress Tolerance in Salix sp Reveal the Importance for a Metaorganismal de Novo Assembly Approach for Nonmodel Plants. Plant. Physiol. 2016, 171, 3-24. [CrossRef] [PubMed]

76. Zhang, J.; Yuan, H.W.; Li, Y.J.; Chen, Y.H.; Liu, G.Y.; Ye, M.X.; Yu, C.M.; Lian, B.L.; Zhong, F.; Jiang, Y.N.; et al. Genome sequencing and phylogenetic analysis of allotetraploid Salix matsudana Koidz. Hortic. Res. 2020, 7, 11. [CrossRef] [PubMed]

77. Kosinski, P.; Sekiewicz, K.; Walas, L.; Boratynski, A.; Dering, M. Spatial genetic structure of the endemic alpine plant Salix serpillifolia: Genetic swamping on nunataks due to secondary colonization? Alp. Bot 2019, 129, 107-121. [CrossRef] 